\title{
Ossifying Renal Tumor of Infancy
}

National Cancer Institute

\section{Source}

National Cancer Institute. Ossifying Renal Tumor of Infancy. NCI Thesaurus. Code C66774.

A benign neoplasm of the kidney occurring in infants. It develops as an intracalyceal mass and is characterized by the presence of osteoid formation, osteoblast-like cells, and spindle cells. 